\title{
Strongyloides 'Larva Currens' Following High Dose Dexamethasone for Upper Airway Burns: A Case Report and Brief Review of the Literature
}

\section{Nicholas J Fischer}

Dunedin Hospital, Great King Street, Dunedin 9016, New Zealand

*Corresponding author: Nicholas J Fischer, Dunedin Hospital, Great King Street, Dunedin 9016, New Zealand, E-mail: Fischer_9@hotmail.com

Received date: January 24, 2015, Accepted date: February 25, 2015, Published date: March 1, 2015

Copyright: (c) 2015 Nicholas J Fischer. This is an open-access article distributed under the terms of the Creative Commons Attribution License, which permits unrestricted use, distribution, and reproduction in any medium, provided the original author and source are credited.

\begin{abstract}
This case report describes a case of Strongyloides 'Larva currens' following high dose dexamethasone for upper airway burns following a fat fire. The patient who was originally from Samoa had been living in New Zealand for over 30 years. This case report reviews the literature surrounding Strongyloides hyperinfection and strongyloides in Samoa.
\end{abstract}

Keywords: Strongyloides; Larva currens; Hyperinfection; Samoa; Immunosuppression; Burns

\section{Case Report}

A 58-year-old Samoan man who had been living in New Zealand for over 30 years with no other overseas travel, presented to our Hospital following cooking fat and flame burns to both hands and his face. On examination he had deep dermal burns to the dorsal left hand, and more superficial burns to his right hand and face with total body surface area burns of $4 \%$. He was also noted to have burns to his nasal passages and oropharyngeal mucous membranes as a result of hot gas and smoke inhalation.

He was treated with intravenous dexamethasone $8 \mathrm{mg}$ twice daily for his airway burns, and received 5 doses in total. He underwent surgical debridement of his left hand burn and split skin grafting under general anaesthesia. On day 6 of admission he spiked a fever of 38 degrees celsius. He complained of an acute pruritic rash on his right flank. He denied abdominal pain or diarrhoea. On examination, his chest was clear on auscultation. He had a characteristic papular, serpiginous rash with a surrounding red flare on his right flank. The rash had a classical appearance of 'larva currens'. An elevated eosinophil count of $0.6 \times 10^{9} / \mathrm{L}(8 \%)$ was also noted from his admission full blood count. A chest X-ray taken was unremarkable. A blood sample was taken and sent for Strongyloides serology. The larva currens' rash dissipated after several hours.

His skin graft was successful and he was discharged home. His Strongyloides serology EIA (Bordier affinity Strongyloides ratti) test was strongly positive with an IgG EIA ratio of 2.02 (positive >1.2). $\mathrm{He}$ was referred to an Infectious Diseases Physician and was treated for Strongyloides infestation with a course of oral Ivermectin $200 \mu \mathrm{g} / \mathrm{kg}$ for 2 days.

Strongyloides is a parasitic nematode that causes the parasitic infestation Strongyloidiasis. This soil-transmitted helminth can reproduce indefinitely in the warm and moist soils of tropical countries. If the larvae comes into contact with human skin, (e.g. barefoot walking on soil) it can penetrate through to enter the circulation [1]. From the circulation, it migrates from the lung capillaries, penetrating the alveoli and into the respiratory tract, then migrates into the gastrointestinal tract [1]. The larvae develop in the duodenum and jejunum and produce ova, which hatch in the Gastrointestinal tract. The hatched larvae pass with stool and thrive in warm moist soil awaiting contact with the next hosts' skin [1].

Strongyloides is unique to other soil transmitted helminths', (e.g. hookworm and roundworm) in that its larvae may 'autoinfect' the host by invading through the bowel mucosa or the perianal skin [1]. This allows the parasite to complete its life cycle independent of an external soil lifecycle and the host may be infected for decades [1,2]. 'Larva currens' is an urticarial type rash resulting from of a localised allergic response to the parasite larvae migrating through the skin in cases of autoinfection. The rash of 'larva currens' occurs on the trunk, moves quite rapidly $(2-10 \mathrm{~cm} / \mathrm{h})$, is not indurated and has a red flare and disappears in hours [1]. 'Larva currens' was reported in Allied prisoners of the Second World War more than 37 years after exposure, often, in times of immunosuppression [2].

Strongyloides infestation in patients with immunosuppression may result in a disseminated 'hyperinfection' $[1,3,4]$. In the process of autoinfection from the GI tract, the parasite may introduce bacteria into the bloodstream and cause a Gram negative bacteraemia and sepsis [1]. Respiratory symptoms and signs have also been ascribed to the parasites journey through the respiratory tract, causing a form of 'Löffler's syndrome' [1,5]. Diagnosis is usually by stool microscopy of the larvae, however serology tests are rapid, easy to perform and highly sensitive and specific for the diagnosis of strongyloidiasis [1,6-8]. Furthermore, seroreversion has been demonstrated in response to eradication with Ivermectin, indicating positive serology is consistent with a current infestation [9].

Very little has been published on the prevalence of Strongyloides in Samoa. It is however known to be present throughout the South Pacific Islands including Samoa [3,9,10]. Literature on Strongyloides in New Zealand is also scarce. While not endemic to New Zealand [11], a handful of case reports of Strongyloides infections occurring in immunocompromised individuals are noted [12-14]. It has also been detected in refugees screened on entry to New Zealand, and in Soldiers and Police officers returning from deployment in endemic countries [15-18]. It is entirely possible therefore that many people living in New Zealand who are from or have visited endemic countries have an undiagnosed Strongyloides infection. 
Citation: NJ Fischer (2015) Strongyloides 'Larva Currens' Following High Dose Dexamethasone for Upper Airway Burns: A Case Report and Brief Review of the Literature. Trop Med Surg 3: 1000180. doi:10.4172/2329-9088.1000180

Page 2 of 2

It is highly likely that our patient's 'larva currens' was triggered by the immunosuppressive effects of high dose dexamethasone. Interestingly, our patient could not recall any similar rash in the past or any chronic abdominal symptoms. This case report illustrates the potentially unrecognized burden of Strongyloides in New Zealand, and the potential for it to cause complications in immunosuppression. Doctors should be mindful of Strongyloides infection in patients from, or who have lived in endemic countries when prescribing immunosuppressive medications.

\section{Acknowledgment: I would like to thank Dr Jill Wolfgang.}

Conflict of interest: The Author declares no conflicts of interest.

\section{References}

1. Farrar J, Hotez P, Junghanss T, Kang G, Lalloo D, White NJ (2013) Manson's Tropical Diseases. 23rd ed. 783-788.

2. Grove DI (1980) Strongyloidiasis in Allied ex-prisoners of war in southeast Asia. Br Med J 280: 598-601.

3. Kline K, McCarthy JS, Pearson M, Loukas A, Hotez PJ (2013) Neglected tropical diseases of Oceania: review of their prevalence, distribution, and opportunities for control. PLoS Negl Trop Dis 7: el755.

4. Hirschmann JV, Plorde JJ, Ochi RF (1984) Fever and pulmonary infiltrates in a patient with a renal transplant. West J Med 140: 914-920.

5. Sheorey H, Walker JC, Biggs BA (2000) Clinical Parasitology: A Handbook for Medical Practitioners and Microbiologists. Melbourne University Press.

6. Bon B, Houze S, Talabani H, Magne D, Belkadi G, et al. (2010) Evaluation of a rapid enzyme-linked immunosorbent assay for diagnosis of strongyloidiasis. J Clin Microbiol 48: 1716-1719.

7. Bisoffi Z, Buonfrate D, Sequi M, Mejia R, Cimino RO, et al. (2014) Diagnostic accuracy of five serologic tests for Strongyloides stercoralis infection. PLoS Negl Trop Dis 8: e2640.
8. Van Doorn HR, Koelewijn R, Hofwegen H, et al. (2007) Use of EnzymeLinked Immunosorbent Assay and Dipstick Assay for Detection of Strongyloides stercoralis Infection in Humans. Journal of Clinical Microbiology 45: 438-442.

9. Page WA, Dempsey K, McCarthy JS (2006) Utility of serological followup of chronic strongyloidiasis after anthelminthic chemotherapy. Transactions of the Royal Society of Tropical Medicine and Hygiene 100: 1056-1062.

10. McCarthy DD, Marples MJ, Bacon DF, Fitzgerald N (1955) Researches in Western Samoa. I. General sanitation and intestinal parasites. Trans R Soc Trop Med Hyg 49: 71-75.

11. Andrews JRH (1976) The parasites of man in New Zealand: A review. New Zealand journal of zoology 3:59-67.

12. Morris A, Van der Merwe W, Simpson I (1987) Fatal strongyloidiasis in a renal transplant patient. N Z Med J 100: 427.

13. Powles AC (1973) Strongyloides stercoralis hyperinfection: case report. $N$ Z Med J 77: 169-171.

14. Thomas MC, Costello SA (1998) Disseminated strongyloidiasis arising from a single dose of dexamethasone before stereotactic radiosurgery. International journal of clinical practice 52: 520-521.

15. McLeod A, Reeve M (2005) The health status of quota refugees screened by New Zealand's Auckland Public Health Service between 1995 and 2000. N Z Med J 118: U1702.

16. Jamieson MG (1970) Strongyloides stercoralis infection in a serviceman in South East Asia. N Z Med J 72: 396-398.

17. Pattison DA, Speare R (2008) Strongyloidiasis in personnel of the Regional Assistance Mission to Solomon Islands (RAMSI). Med J Aust 189: 203-206.

18. Visser JT, Narayanan A, Campbell B (2012) Strongyloides, dengue fever, and tuberculosis conversions in New Zealand police deploying overseas. J Travel Med 19: 178-182. 